\title{
Pedagogical aspect of information and communication technologies influence upon the educational space
}

\author{
Svetlana V. Ivanova, ${ }^{1, *}$ \\ ${ }^{1}$ ISED RAE, director,105062, Moscow, Russia
}

\begin{abstract}
The author defines the range of problems connected with forming and changing of educational space and educational milieu under the influence of information and communication technologies. The notions "space" and "milieu" are reconsidered in the frame of this theme. Comparing existing general positive background of the development of information technologies in educational space the author discloses the risks of endless and uncontrolled development of infocommunications, their specificity in the postmodern epoch, the role of information from the viewpoint of non-classic methodology.
\end{abstract}

Before we look at the influence of information and communication technologies upon the educational space let's consider the essence of notions "space" and "milieu" which have become so widely used in the science of pedagogy and practice of education.

During last decade in the published materials we can find an amazing variety of interpretations for the notions of educational space and educational milieu, however, up to date they practically have never been included into pedagogical encyclopedia, professional dictionaries, legal texts and monographs dedicated to the terminology in education.

In particular, this notion is missed in the UNESCO: IBE Education Thesaurus of 1983 [1], is not considered by Valentin M. Polonskiy in "Subject heading list: Secondary school. Pedagogy of the secondary school" [2], in Pedagogic Encyclopedia etc.

Certainly, we should take into account philosophical position interpreting the notion of "space". Therefore, in the New philosophical Encyclopedia it is said: "Space is 1) the form of contemplation, perception of representation of objects, the main factor of the highest empirical experience; 2) the way of existence of the objective world, inseparably connected with time [3].

Generalizing a number of concepts described in scientific publications, let's fix that educational space is the objective world, the integrity of objects, related to the education of objects creating and filling in this space, and at the same time it is an object of subject-related activity consisting in perception, action and influence of subjects upon this space [4].

It is important to warn against interpretation of the terms educational space and educational milieu as identical or synonymous [5].

What is educational milieu? The term "milieu" is polysemantic, depending on a great number of objectrelated spheres where it can be applied, nevertheless, in philosophical dictionaries this term is not defined. There is an interesting interpretation for it in Oxford Dictionary of Psychology, where it is noted that the term comes from French and can be approximately translated as "to surround". Therefore, milieu is what surrounds, and this general meaning involves a wide range of the ways to use. Usually this term includes a definition allowing us to understand what exactly is surrounded. This term also has a connotation of influence, i.e. it means something that is a part of a given being and plays a certain actual or potential role in the life of this being [6].

Let's consider one more definition: "milieu is the totality of natural or social conditions where human society exists and develops. Social and living conditions where man lives, environment, the population connected by the community of conditions and settings" [7]. We assume J. Dewey to be the first to speak about educational milieu as the creation of conditions in the beginning of the $20^{\text {th }}$ century [8]. We can find this idea in a certain interpretation in many of his works. We also can add that at least V.V. Davydov, L.S. Vygotsky, A.N. Leontiev, D.B. Elkonin etc. concerned the problem of educational milieu, which could be changed during activity [9]. A.M. Novikov stated that "educational milieu is the system of impacts and conditions of personality forming as well as the possibilities for its development existing in social and spatial-object surroundings" [10]. Following Novikov, I.M. Elkina defines milieu as "a certain complex of conditions for realization or proceeding of a certain process" [11]. We can find a great number of more or less similar definitions $[12,13,14,15]$.

We would like to extend these conceptions. Educational milieu is the environment of the participants of educational process in the space of education, including pedagogical conditions, situations and the system of relations between individuals united with the 
commonness of pedagogical and educational activity. Educational milieu acquires the qualitative features, its own milieu-related factors and a multilevel structure with vertical interrelations between the structural levels. Educational milieu is a part of a megasystem for social environment [4].

Qualitative features of educational milieu are connected with the result of its influence on the subjects of educational process; the quality of educational milieu is directly connected with the evaluation of the quality of education. Here the milieu is the outcome of purposeful efforts of subjects realizing their activity in it under the influence of various factors. This dichotomy reveals itself during reciprocal influence of both space and milieu; however, it is rational to look at the influence of information and communication technologies on educational milieu and formation of educational space from this point of view.

To a certain extent, information and communication technologies represent the object of educational space, but the object which is not the same with the other objects: institutions, organizations etc. This object has got its own explicit specificity. First of all, we should mention its penetrating nature. Information and communication technologies pierce through educational space. Secondly, while evaluating this penetrating effect it is reasonable to indicate the specificity of its qualitative characteristics. In particular, its progressive peculiarity: the higher the level of information technologies, the quality of hardware and professional skills of the personnel, the more modern is educational space and the more efficient its influence upon the objects and subjects included into this space. It can be seen by the example of Smart-technologies.

At the same time, it is necessary to take into account that the super-modern equipment and highly skilled staff providing the opportunity for efficient solution of educational problems can affect not only positive but negative influence on the subject of activity. For instance, together with a successful learning with the help of ICT it is possible to become addicted to Internet, to acquire anxiety and to lose social communications in the real world.

Information technologies offer wide possibilities in acquisition, mastering and control of considerable volume of knowledge. However, this knowledge easily obtained by a man with a high level of ICT literacy will not become a descriptive factor of his/her professional successfulness. The point is that in the modern world it is important not only "to know", but "can be" and be able to "acquire knowledge". In this case we mean competences. The activity forming them becomes predominant and it is provided by the information communication technologies to the best advantage.

Interaction and reciprocal influence of educational space and educational milieu based upon the wide use of ICT further appearance, increment of the new knowledge, changes in educational milieu. All this takes place through information and technologies.

This thought can be exemplified by the well-know idea of J. Derrida about the world as text [16]. Everything belonging to the cultural sphere is text understood as sign, symbol. Due to the development of information communications and a huge amount of information which can be estimated in Mega-, Giga- and other bytes in certain cases, it becomes clear that information is a hypertext having a capacity to be originated in the new variations. The process of representation and interpretation is permanent, and text, sign, forming strata and spreading about, brings new interpretations.

Appearance and development of information and communication technologies, on the one hand, can be treated as an attempt to create - possibly imaginary mechanism of a certain management of information (knowledge, as the ancients understood it). It is not a surprise that with the time this incontrollable process would intensify. On the other hand, ICT can be considered as an outcome of this new world, the world of intertextuality (according to Yu. Kristeva) [17] where the text predominates over the subject. "Any text is built as mosaics of citations; any text is the product of absorbing and transformation of another text. Thus, the notion of intertextuality replaces the notion of intersubjectivity" [17]. This statement demonstrates the significance of these (maybe, ineffective) attempts to restrain the text power, maintenance of the dialogic communication channel, preserving intersubjectivity.

Nowadays the obvious fact is the existence of keenness on technological processes. This keenness originates from aspiration for the development and intensification of information and communication technologies, for creation of special communicative environment via telecommunication channels and creation again the same aspiration. The problem of loss a direct, non-mediated by telecommunication equipment dialog is not sharp yet. However, we cannot help noticing it while forming educational process based on information technologies, because the lack or minimization of dialogic communication, replacement of intersubjective relations by interaction with text changes drastically educational space, thus it influences the changes of its subjects and objects. Certainly it is necessary to understand the intensity of influence of information technologies on educational space and educational milieu. In the context of all positive meaning of the development of information technologies, it is necessary to take into account those risks which influence educational space and subject-related activity in its frame.

There are many works about the advantages of information technologies and distance education. During the development of this technological phenomenon there will be more benefits, creating more comfortable environment for people, and we assume their number to increase in future. There are much fewer works about negative tendencies besides those, which are evident (low-quality education, distance education as a legal form of buying a graduate degree etc.). The negative information of this kind is a distinctive feature of education with the help of information technologies.

One more serious problem, which, in the opinion of many researchers, cannot be solved yet, is the creation of a special world of the so-called virtual reality, in which 
the subject can immerse so deep that he/she falls out of the real world. There are more and more people who are morbidly addicted to computer. In other words, the subject loses his own worlds as a personality, as an individual, remaining in the world of information, cognizing the real world through mental subject-related world, which has become the object of information attack. Here we can state again that this change of subject (why cannot we assume that it can occur partially under the influence of directed and preplanned education in the form of distance technologies?!) leads to sharp changes in educational space and gradually leads to the qualitative changes of social environment. These phenomena are being observed now [18].

Next risk is due to the fact that information and communication technologies begot special communicative strategies. In each sphere they have special features, as well as in educational space, where there are its own communication networks, communities, and communicative strategies develop in the management sphere. There are many positive examples here: the development of distance education, discussion of bills and certain concepts via electronic discussion, creation of positive network communities favoring improvement of activity of both individual objects and subjects of educational space and its development in general. The influence of information communications on the personality is described in many works of modern scientists. However, there are two sides of the coin. Unfortunately, communicative strategies in education and science management, online community are often characterized by manipulative practices of various kinds, negative as well. Electronic PR-technologies are quite an efficient means of specific management for educational space influencing personality.

For the development and positive impact of information and communication technologies upon educational space and avoiding risks it is important taking into account specificity of information technologies:

- to build a special system of their management (based on their own use);

- to organize specialized training for subjects of educational space, in general - the society actors, in mastering these technologies, to identify the nature and direction of communicative strategies and to build corresponding relationship; rejection of living (contact) interaction reduces personality security against influence of information technologies, opens the access to the sources of harmful data flow, furthers extreme virtualization of human life;

- to plan and fund realization of programs for providing favorable and lowering the risks of negative impact of information and communication technologies on the objects and subjects of educational space;

- to intensify training in the humanities and forming moral values of students studying professions connected with information technologies;

- to improve legal framework in the sphere of the use of information technologies [19].

\section{References}

1. UNESCO: IBE Education Thesaurus of 1983 (Moscow, 1983) [In Rus]

2. V.M.Polonskii, Rubrikator "Obshcheobrazovatel'naya shkola. Pedagogika obshcheobrazovatel'noi shkoly" (Informatsionnoanaliticheskii tsentr, Moscow, 2006) [In Rus]

3. Novaya filosofskaya entsiklopediya (Mysl', Moscow, 2010) [In Rus]

4. S.V. Ivanova, Tsennosti i smysly, 6, (2015) [In Rus]

5. Pedagogicheskii terminologicheskii slovar' (Rossiiskaya natsional'naya biblioteka, St.Petersburg, 2006) [In Rus]

6. Oksfordskii tolkovyi slovar' po psikhologii. Available online URL: http://vocabulary.ru/dictionary/487/word/sreda (accessed on: 5.07.2015) [In Rus]

7. D.N. Ushakov, Tolkovyi slovar' russkogo yazyka (Moscow, 2000) [In Rus]

8. J. Dewey, Shkola $i$ obshchestvo (Rabotnik prosveshcheniya, Moscow, 1922) [In Rus]

9. Avtorskii terminologicheskii slovar' L.S. Vygotskogo. Available online at URL: http://vygotsky.academic.ru/152 (accessed on: 17.06.2014) [In Rus]

10. A.M. Novikov, Pedagogika: slovar' sistemy osnovnykh ponyatii. (Izdatel'skii tsentr IET, Moscow, 2013) [In Rus]

11. I.L. Klimenko, I.M. Elkina, ETAP, 1 (2014) [In Rus]

12. G.Yu. Belyaev, Pedagogicheskaya kharakteristika obrazovatel'noi sredy $v$ razlichnykh tipakh obrazovatel'nykh uchrezhdenii (Moscow, 2006) [In Rus]

13. O.B. Ivanov, ETAP, 1, (2014) [In Rus]

14. Yu.N. Kulyutkin, Obrazovatel'naya sreda $i$ razvitie lichnosti. Available online at URL: http://znanie.org/jornal/n1_01/obraz_sreda.html (accessed on: 23.01.2016) [In Rus]

15. I.K. Shalaev, A.A. Veryaev, Ot obrazovatel'nykh sred $k$ obrazovatel'nomu prostranstvu: ponyatie, formirovanie, svoistva. Available online at URL: http://www.unialtai.ru/Journal/pedagog/pedagog_5/a03.html (accessed on: 28.02.2014) [In Rus]

16. J. Derrida, Letter to a Japanese Friend. (Prof. Izutsu) (Parousia Press, Warwick 1985)

17. Yu. Kristeva, Vestnik MGU, Filologiya, 1, (1995) [In Rus]

18. K.S. Sharov, Tsennosti i Smysly, 6 (2013) [In Rus]

19. S.V. Ivanova, Prostranstvo i Vremya, 3 (2013) [In Rus] 